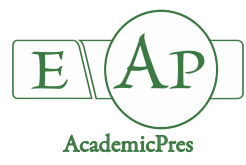

\title{
Evaluation of the Phytochemical, Antioxidant, Antibacterial and Anticancer Activity of Prunus domestica Fruit
}

\author{
Hossam S. EL-BELTAGI ${ }^{1,2 *}$, Abeer E. EL-ANSARY', Mai A. MOSTAFA ${ }^{3}$, \\ Teba A. KAMEL ${ }^{3}$, Gehan SAFWAT ${ }^{3}$ \\ ${ }^{1}$ Cairo University, Faculty of Agriculture, Biochemistry Department, Giza, Cairo, Egypt; \\ belbeltagi@agr.cu.edu.eg (*correspondingauthor); abeeransary@yahoo.com \\ ${ }^{2}$ Cairo University, Research Park (CURP), Giza, Cairo, Egypt \\ ${ }^{3}$ October University for Modern Sciences and Arts (MSA), Faculty of Biotechnology, Egypt; mai.alaa@msa.edu.eg; \\ teba.abdelrahman@msa.edu.eg;gehan.safwat@hotmail.co.uk
}

\begin{abstract}
Plants have been used long ago through man history of life for their use in food and medicinal drives. In modern life, natural products have been extracted and isolated from several kinds of plants for the development of new drugs. There are numerous interests in natural antioxidants extracted from medicinal plants, vegetables and fruits, which might help to prevent oxidative damage. One of such plants is plum Prunus domestica L., family Rosaceae. Samples from 'African Rose', and 'Santa Rosa' plum cultivars were collected from local market in Giza governorate, Egypt. The main phytochemicals of plums (fruit flesh and skin) were analyzed. Total polyphenols, flavonoids, tannins, anthocyanins, and reducing power were higher in 'African Rose' fruit. The ethanolic and ethyl acetate extracts of two plum cultivars were both high in the antioxidant effect with IC 5013.923 and $18.416 \mu \mathrm{g} / \mathrm{ml}$ of ethanolic extract of 'African Rose', and 'Santa Rosa' respectively. The IC $\mathrm{C}_{50}$ of 'African Rose' and 'Santa Rose' extract against Caco-2 was 4 and $8.5 \mu \mathrm{g} / \mathrm{ml}$. GC-MS analysis was carried out, fourteen and twenty one compound were identified in 'Santa Rosa' and 'African Rose' respectively. The fruits had an antimicrobial action against gram positive and negative bacteria. There was anticancer activity against 3 cell lines: Liver cell line (HepG2), colorectal adenocarcinoma (Caco-2) cell line, and breast cell line (MCF-7).
\end{abstract}

Keywords: antibacterial; anticancer activity; antioxidant; DPPH; flavonoid; phenols; plum extract

\section{Introduction}

Medicinal plants have been widely used for therapeutic purposes since ancient times. The beneficial effects of fruits and vegetables are generally ascribed to the presence of phenolic compounds for example phenolic acids, flavonoids, tannins, and nitrogen compounds such as alkaloids and amines, as well as vitamins, terpenoids and other metabolites, which have a high antioxidant activity (Cai $e t$ al., 2004; Djeridane et al., 2006; Yang et al., 2009; AbdelRahim and El-Beltagi, 2010). This activity is because of the ability of these materials to reduce oxidative stress by neutralizing or scavenging of reactive species by hydrogen donation, before they attack cells and other biological components (Kobeasy et al., 2011; Erkan, 2012; Kesba and El-Beltagi, 2012). Reactive oxygen (ROS) and nitrogen (RNS) species are products of normal cellular metabolism. However, at high concentrations, these species may be significant mediators of damage to cellular structures, such as proteins, lipids and nucleic acids. The oxidation of any of these substrates, if uncontrolled, can contribute to the development of chronic diseases like cancer, hypertension, diabetes mellitus, cardiovascular and neurodegenerative diseases (Valko et al., 2007; Shallan et al., 2010). In this sense, there is great concern in finding natural antioxidants from plant materials, and various extracts and isolated compounds have been studied for their antioxidant activity, using different methods (El-Beltagi, 2011; Costa et al., 2012; El-Beltagi et al., 2018).

Plums are part of the Rosaceae family, Prunus genus. The fruits display a wide range of size, color, flavor, and texture (Dugalic et al., 2014). Consumers appreciate plum fruits for their flavour, color and aromatic features. High consumption of fruits and vegetables was linked to reduced incidence of degenerative diseases owing to their potential antioxidant capacity (Prior, 2003). It is considered as a respectable source of nutrients due to the content of ascorbic acid, monosaccharides, various minerals, dietary fiber, and phenolics, such as chlorogenic, benzoic, vanillic, 
396

and caffeic acid (Karabegovic et al., 2014). These factors may supply important information to the consumer in terms of identifying a more nutritional fruit. The fruit of $P$. domestica is a potent antibacterial activity (Yaqeen et al., 2013). It is dried fruit contains large amounts of antioxidant constituents, such as neochlorogenic acid (3-Ocaffeoylquinic acid), chlorogenic acid (5-O-caffeoylquinic acid), cryptochlorogenic acid (4-O-caffeoylquinic acid), (+)abscisic acid, (+)- $\beta$-D-glucopyranosyl abscisate, (6S,9R)roseoside, and two lignan glucosides $[(+)$-pinoresinol mono- $\beta$ - D-glucopyranoside and 3-( $\beta-D$ glucopyranosyloxymethyl)- 2 -(4-hydroxy-3-methoxyphenyl)-5 -(3-hydroxypropyl)-7 -methoxy-(2R,3S) -dihydrobenzofuran] (Kikuzaki et al., 2004 and Kayano et al., 2002). In addition, the fruit contains flavonols (myricetin, quercetin, and kaempferol), carbohydrates (fructose, sucrose, glucose, sorbitol), organic acids (citric acid, malic acid), vitamins ( $\alpha$-tocopherol, $\gamma$-tocopherol, $\beta$-carotene), and minerals (sodium, potassium, magnesium, calcium, iron, zinc) (Lombardi-Boccia et al., 2004). The aim of this work was to evaluate of the phytochemical composition of Prunus domestica fruit cultivars ('Santa Rosa' and 'African Rose') and to study their effects as an antioxidant, antimicrobial and anticancer activity.

\section{Materials and Methods}

\section{Plantmaterial}

Plums cultivars 'African Rose', and 'Santa Rosa' were collected from a local market in Egypt. Prunus domestica was botanically categorized by Dr. Samah Azooz - Botany Department, Faculty of Agriculture, Cairo University, Egypt.

\section{Microbialstrain}

Table 1 showed the microorganisms which were used in this study and were acquired from the American Type Culture Collection (ATCC) in addition to the culture collection of the Microbiology Lab, Cairo University Research Park (CURP), Faculty of Agriculture, Cairo University.

\section{Extraction method}

The fruits were cleaned and washed thoroughly under tap water, and then the fruits were freeze-dried and grinded into fine powder using an electric blender. The powder was dehydrated in an oven at $40{ }^{\circ} \mathrm{C}$ for $24 \mathrm{~h}$. The fine powder sample $(500 \mathrm{mg})$ was extracted in $10 \mathrm{ml}$ ethanol or ethyl acetate for $24 \mathrm{~h}$ using a shaker, then the extract was filtered and the samples were stored at $4{ }^{\circ} \mathrm{C}$ until use (Sumathy and
Sumathy, 2011). All analysis was done in the labs of Cairo University. Research Park (CURP), Faculty of Agriculture, Cairo University, Cairo, Egypt.

\section{Total polyphenolic content}

The total phenols content was assessed by Folin Ciocalteu technique as described by Singleton and Rossi (1965). The absorbance was measured at $765 \mathrm{~nm}$ with spectrophotometer Thermo Scientific HERYIOS.

\section{Total flavonoid content}

The flavonoids content was determined by aluminium trichloride method as described by Zhishen et al. (1999). The absorbance was measured at $510 \mathrm{~nm}$ with a spectrophotometer.

\section{Total tannin content}

Tannin content in plums was determined using FolinDenis reagent as mentioned by Saxena et al. (2013). The absorbance was read at $700 \mathrm{~nm}$ using spectrophotometer.

\section{Total alkaloids content}

Alkaloids were measured according to the method described by Harbone (1998). The absorbance was taken at $565 \mathrm{~nm}$. The alkaloid concentration was calculated from the calibration curve of atropine used as standard and results expressed as $\mathrm{g} / 100 \mathrm{~g}$ equivalent of atropine.

\section{Total anthocyanin (TA) content}

The total anthocyanin contents were determined by the $\mathrm{pH}$ differential method (Lee et al., 2005) using a spectrophotometer (Thermo Scientific HERYIOS). The absorbance of the fruit extract was measured at 515 and 700 $\mathrm{nm}$ in $\mathrm{pH} 1.0$ and 4.5 buffers, respectively, using $\mathrm{A}=(\mathrm{A} 515$ - A700) pH 1.0 - (A515 - A700) pH 4.5 with a molar extinction coefficient of 26,900. The results were expressed as $\mathrm{mg}$ of cyanidin-3-glucoside equivalent per 100 grams of fresh weight.

\section{Determination of reducing power}

The ability of the tested extracts to reduce $\mathrm{Fe}^{3+}$ was done by the method of Chou et al. (2009). The absorbance was measured at $700 \mathrm{~nm}$. The results were expressed as $\mu \mathrm{g}$ of gallic acid equivalent per $100 \mathrm{~g}$ DW.

\section{DPPH free Radical Scavenging Activity (RSA)}

The antioxidant activity of the Prunus domestica extract was measured in terms of hydrogen donating or radicalscavenging capability using the stable DPPH method as modified by Park et al. (2006).

Tablel. Microbial strains used to test the antimicrobial activities of 'Santa Rosa' and 'African rose' fruit extracts

\begin{tabular}{|c|c|c|c|}
\hline Microbial group & Indicator strain & Positive control & Cultivation conditions \\
\hline \multirow{2}{*}{ Gram positive bacteria } & Staphylococcus aureus (ATCC 25923) & \multirow{2}{*}{ Kanamycin } & Muller-Hinton broth, $37^{\circ} \mathrm{C} / 24 \mathrm{~h}$ \\
\hline & Bacillus cereus (ATCC 33018) & & Muller-Hinton broth, $30^{\circ} \mathrm{C} / 24 \mathrm{~h}$ \\
\hline \multirow{2}{*}{ Gram negative bacteria } & Escherichia coli (ATCC 8739) & \multirow{2}{*}{ Polymyxin } & Muller-Hinton broth, $37^{\circ} \mathrm{C} / 24 \mathrm{~h}$ \\
\hline & Salmonella typhimureum (ATCC 14028) & & Muller-Hinton broth, $37^{\circ} \mathrm{C} / 24 \mathrm{~h}$ \\
\hline \multirow{2}{*}{ Fungus } & Aspergillus niger (nrrl 326) & \multirow{2}{*}{ Nystatin } & Sabouraud dextrose broth, $25^{\circ} \mathrm{C} / 3$ days \\
\hline & Candida albicans ATCC 10231 & & Sabouraud dextrose broth, $25^{\circ} \mathrm{C} / 24 \mathrm{~h}$ \\
\hline
\end{tabular}


The reaction mixture containing $1 \mathrm{ml}$ of the extract at diverse concentrations $(40,80,120,150 \mu \mathrm{g} / \mathrm{ml})+1 \mathrm{ml}$ of DPPH $(0.2 \mathrm{mM})$ was vigorously shaken and incubated in darkness at room temperature for 30 minutes. The absorbance was read at $517 \mathrm{~nm}$ using UV-visible spectrophotometer. Radical scavenging activity was stated as percent of inhibition and was calculated using the following formula:

$\% \mathrm{DPPH}=[$ Absorbance of Control - Absorbance of Sample / Absorbance of Control] $\times 100$.

\section{Extraction of phenolic and flavonoid compounds}

$0.2 \mathrm{~g}$ dry sample extracted with $20 \mathrm{ml}$ ethanol $80 \%$, soak in brown bottle for $24 \mathrm{hr}$ at room temperature, then centrifuged for $5 \mathrm{~min}$, volume adjusted to $25 \mathrm{ml}$ by ethanol $80 \%$, and filtered through Whatman filter paper, $10 \mathrm{ml}$ of the solution evaporated to dryness then dissolved in $5 \mathrm{ml}$ HPLC grade methanol 50\%, and filtered through PTFE filter with pore size $0.2 \mu \mathrm{m}$.

\section{Instrument condition for phenolic compounds}

Agilent 1260 infinity HPLC Series (Ag-ilent, USA), equipped with Quaternary pump, a Zorbax Eclipse plusC18 column $100 \mathrm{~mm} \times 4.6 \mathrm{~mm}$ i.d. (Agilent Technologies, USA), operated at $30^{\circ} \mathrm{C}$. The separation is completed using a ternary linear elution gradient with (A) HPLC grade water $0.2 \quad \% \quad \mathrm{H}_{3} \mathrm{PO}_{4}(\mathrm{v} / \mathrm{v}),(\mathrm{B})$ methanol and (C) acetonitrile. The injected volume was $20 \mu \mathrm{l}$. Detection: VWD detector was set at $284 \mathrm{~nm}$.

Instrument condition for flavonoids

HPLC, Smart line, Knauer, Germany., equipped with binary pump, a Zorbax Eclipse plus C18 column $150 \mathrm{~mm} x$ $4.6 \mathrm{~mm}$ i.d. (Agilent Technologies, USA), operated at 35 ${ }^{\circ} \mathrm{C}$. Eluent: methanol: $\mathrm{H}_{2} \mathrm{O}$ with $0.5 \% \mathrm{H}_{3} \mathrm{PO}_{4}$, 50:50 with flow rate $0.7 \mathrm{ml} / \mathrm{min}$, and the injected volume was $20 \mu \mathrm{l}$. Detection: UV detector set at $273 \mathrm{~nm}$ and data integration by clari-tychrom@ software. This method was the modified of methods Goupy et al. (1999) and Mattila et al. (2000) for fractionate the polyphenols and flavonoids, respectively.

\section{Fruits extraction for GC/MS analysis}

The fruits were washed, shade dried and ground to powder in a mechanical grinder. Required quantity of powder was weighed and transferred to stoppard flask and treated with ethanol until the powder is fully dipped. The flask was shaken every hour for the first 6 hours and then it was kept away and again shaken after 24 hours. This process was repeated for 3 days and then the extract was filtered. The extract was collected and evaporated to dryness using a vacuum distillation unit. The final residue gained was then subjected to GC-MS analysis.

\section{GC-MS analysis}

GC-MS analysis of these extracts was performed using an Agilent 7000 Series Triple, Quad Gas Chromatograph interfaced to a Mass Spectrometer (GC/MS/) equipped With a Elite-5MS (5\% diphenyl / 95\% dimethyl poly siloxane) fused a capillary column $(30 \times 0.25 \mu \mathrm{m}$ ID $\times 0.25$ $\mu \mathrm{m} d f)$. For GC-MS detection an electron Ionization system with ionizing energy of $70 \mathrm{ev}$ was used. Helium gas
(99.999\%) was used as carrier gas at a constant flow rate 1 $\mathrm{ml} / \mathrm{min}$ and injection volume of $2 \mu \mathrm{l}$ was employed (split ratio of 10:1); the injector temperature $250^{\circ} \mathrm{C}$; ion-source temperature $200{ }^{\circ} \mathrm{C}$. The oven temperature programmed from $110{ }^{\circ} \mathrm{C}$ (iso thermal for $2 \mathrm{~min}$ ) with a rise of 10 ${ }^{\circ} \mathrm{C} / \mathrm{min}$ to $200^{\circ} \mathrm{C}$, then $5^{\circ} \mathrm{C} / \mathrm{min}$ to $280^{\circ} \mathrm{C}$, ending with a $9 \mathrm{~min}$ iso thermal at $280^{\circ} \mathrm{C}$, mass spectra were taken at 70 ev: a scan interval of 0.5 second and fragments from 45 to $450 \mathrm{Da}$, total GC Running time was 36 minutes. The relative \% quantity of each component was calculated by relating its average Peak area to the total areas. Software approved to handle mass spectra and chromatograms was Turbomass.

Clarification of mass spectrum GC-MS was conducted using the database of National Institute of Standard and Technology (NIST) having more than 62,000 patterns. The spectrum of the unknown components kept in the NIST library. The name, structure and molecular weight of the components of the test materials were determined (Bagavathi and Ramasamy, 2012).

\section{Antibacterial activity}

Agar disc diffusion method was done to evaluate antibacterial activity of plum as describe by Bauer $e t$ al. (1966). The strains were grown on Mueller-Hinton agar slants at $37^{\circ} \mathrm{C}$ for $24 \mathrm{~h}$ and checkered for purity. After the incubation, the cells were washed off the surface of agar and suspended in sterile physiological solution. The amount of cells in $1 \mathrm{ml}$ of suspension for inoculation measured by McFarland nefelometer was $5 \times 107 \mathrm{CFU} / \mathrm{ml} .1 \mathrm{ml}$ of these suspensions was homogenized with $9 \mathrm{ml}$ of melted $\left(45^{\circ} \mathrm{C}\right)$ Mueller-Hinton agar and dispensed into Petri dishes. On the agar surface, $5 \mathrm{~mm}$ diameter paper discs (HiMedia, Mumbai, India) were applied and impregnated with $15 \mu \mathrm{l}$ of samples. The plates were incubated at the optimal temperature for each indicator strain (Table 1) and tested after 24, 48 and $72 \mathrm{~h}$. Inhibition of growth was scored positive in the presence of a detectable clear zone (ZI) around the disc and expressed in $\mathrm{mm}$. Experiments were car-out in triplicates and the inhibition zone was recorded as the average of the replicates \pm SD.

\section{In vitro cytotoxicity assay}

Human lung cancer (A549), colorectal adenocarcinoma Caco-2, and MCF-7 human breast cancer were purchased from CURP, faculty of agriculture at Cairo University (Egypt). Cells were kept in (DMEM) supplemented with $10 \%$ heat-inactivated fetal bovine serum, $100 \mu \mathrm{g} / \mathrm{ml}$ streptomycin and $100 \mathrm{unit} / \mathrm{ml}$ penicillin g potassium, in a humidified $90 \%$ and $5 \%(\mathrm{~V} / \mathrm{V}) \mathrm{CO}_{2}$ atmosphere at $37^{\circ} \mathrm{C}$. The cytotoxicity of ethanolic extracts was tested by the neutral red (NR) assay as before described (Repetto et al., 2008). Exponentially growing cells were collected using $0.25 \%$ Trypsin-EDTA and seeded in 96- well plates at 20000 cells/well. After incubation (overnight), extracts were added in many concentrations $(10,50,100,200,400$, and $800 \mu \mathrm{g} / \mathrm{ml}$ ); 4 wells for each concentration. After treatment with extracts for $24 \mathrm{~h}$., media were removed and cells were exposed to neutral red solution for 4 hours at 37 ${ }^{\circ} \mathrm{C}$. Destin solution was used to dissolve the NR stained cells and color was measured at $540 \mathrm{~nm}$ microplate reader (Biotek, ELX808). 
398

\section{Statistical analysis}

All results were expressed as mean values \pm standard deviation. Comparisons were performed by analysis of variance (ANOVA). Statistical analyses were run using SAS software.

\section{Results and Discussion}

\section{Phytochemical constituents of plums}

As illustrated in Table 2, the chemical constituents of ethanolic and ethyl acetate extracts of two species of plum fruit extracts 'Santa Rosa' and 'African Rose'. First, for 'Santa Rosa' ethanolic extract contain total phenolic $(122.17 \pm 2.05 \mathrm{mg} / \mathrm{g} \mathrm{DW})$ while ethyl acetate $(64.94 \pm$ $0.16 \mathrm{mg} / \mathrm{g} \mathrm{DW}$ ) and for 'African Rose' ethanolic and ethyl acetate extract $486.08 \pm 4.07$ and $116.849 \pm 1.15 \mathrm{mg} / \mathrm{g}$ DW respectively. Total phenolic content is frequently used to measure the antioxidant properties of plant extracts since it constitutes an effective, fast and inexpensive assay (Dai and Mumper, 2010). A direct relationship has been detected between the total polyphenolic contents and antioxidant activity of several natural product extracts (Vinson et al., 2001). Several studies have examined the polyphenolic content of different species of the genus Prunus, Demir et al. (2017) found that Total polyphenolic content was $33.7 \pm 0.13 \mathrm{mg}$ GAE per g sample of Prunus laurocerasus. The total polyphenolic content values of many extracts of $L$. officinalis fruits from different regions are reported to range between 23.6 and $64.6 \mathrm{mg}$ GAE per g extract (Orhan and Akkol, 2011; Celep et al., 2012). Another study showed that ethyl acetate extract got $33.88 \pm$ $0.18 \mathrm{mg} / \mathrm{g}$ of total poly phenolic content (Dhingra et al., 2014). According to one article, methanolic extract has 4.42 $\mathrm{mg} / \mathrm{g}$ dry weight (Eivind and Rune, 2006); However, Gil et al. (2002) found that, phenolics content varied from 0.42 to $1.09 \mathrm{mg} / \mathrm{g}$ fresh weight in five plum cultivars, while, Kim et al. (2003) found a range from 1.74 to $3.75 \mathrm{mg} / \mathrm{g}$ fresh weight in six plum cultivars. Vlaic et al. (2017) found that the phenolics measured from the plum samples varied between 60.31 and $699.92 \mathrm{mg} \mathrm{GAE} 100 \mathrm{~g}^{-1}$.

Results stated by Díaz Mula et al. (2009), admiring that the variety has a very significant role in the biosynthesis of phenolic compound. Another study showed that the total phenolic content of dried plum was found to be $1.05 \mathrm{mg}$ GAE/100 mg extract (Mehta et al., 2014). In the same concern, Sójka et al. (2015) found that polyphenol content was found in plums pomaces was $50 \mathrm{~g} / 100 \mathrm{~g}$.

As flavonoids are well recognized antioxidants, it is thought that the plants which are high in flavonoids have strong antioxidant activity. The highest value of total flavonoid was for ethanolic extract of 'African Rose' (45.991 $\pm 1.26 \mathrm{mg} / \mathrm{g} \mathrm{DW})$, then its ethyl acetate extract (35.61 \pm $1.07 \mathrm{mg} / \mathrm{g} \mathrm{DW}$ ) then 'Santa Rosa' ethanolic extract with value $(30.02 \pm 0.15 \mathrm{mg} / \mathrm{g} \mathrm{DW})$ and the lowest value was for 'Santa Rosa' ethyl acetate extract $(15.79 \pm 0.37 \mathrm{mg} / \mathrm{g}$ DW). Dhingra et al. (2014) reported that a proper amount of total flavonoid content $(47.96 \pm 0.36 \mathrm{mg} / \mathrm{g})$ was found to be existing in ethyl acetate fraction of $P$. domestica, while minimum concentration was existing in the hexane fraction $(2.06 \pm 0.3 \mathrm{mg} / \mathrm{g})$. Result of an earlier report was $1.03 \mathrm{mg}$ $/ \mathrm{g}$ fresh weight of flavonoids in the pulp of $P$. domestica pulp (Sandra et al., 2009). Another study submitted that the total flavonoid content of dried plum was $0.583 \mathrm{mg}$ $\mathrm{CE} / 100 \mathrm{mg}$ extract (Mehta et al., 2014). So our process seems to provide a much better yield in ethanol and ethyl acetate fractions.

Total tannins were high in ethanolic extract of 'African Rose' and 'Santa Rosa' to give $9.355 \pm 0.21$ and $8.71 \pm 0.14$ $\mathrm{mg} / \mathrm{g}$ DW respectively. Contrarily, the 'Santa Rosa' is higher in total alkaloids with values $4.84 \pm 0.08$ and $3.74 \pm$ $0.11 \mathrm{mg} / \mathrm{g}$ DW for ethanolic and ethyl acetate fruit extracts respectively. Then the 'African Rose' got lower values 2.425 \pm 0.31 and $1.316 \pm 0.11 \mathrm{mg} / \mathrm{g}$ DW for ethanolic and ethyl acetate fruit extracts respectively.

Total anthocyanin was the highest in 'African Rose' ethanolic extract to give $326.83 \pm 1.68 \mathrm{mg} / \mathrm{g}$ DW followed by its ethyl acetate extract $206.48 \pm 2.08$, then 'Santa Rosa' ethanolic extract 164.131 .78 , then the ethyl acetate extract $97.51 \pm 0.46 \mathrm{mg} / \mathrm{g}$ DW. Vlaic et al. (2017) found that the amount of anthocyanins during maturity was between 1.65 to $1.76 \mathrm{mg} \mathrm{CE} 100 \mathrm{~g}^{-1}$.

\section{Antioxidant activity of plums}

The effect of antioxidants on DPPH radical scavenging was assumed to result from their hydrogen donating capability. DPPH is a stable free radical and accepts an electron or hydrogen radical to develop a stable molecule. DPPH is a stable free radical compounds and has an absorbance in its oxidized form around $515-520 \mathrm{~nm}$. It is visually clear as a discoloration from purple to yellow. The scavenging of DPPH radicals increased with increasing extract concentration from 40,80, 120 and $150 \mu \mathrm{g} / \mathrm{ml}$ (Table 3). The best $\mathrm{IC}_{50}$ was the value of ethanolic extract of 'African Rose' $(13.923 \mu \mathrm{g} / \mathrm{ml})$ followed by the ethanolic

Table 2. Quantitative phytochemical analysis of 'Santa Rosa' and 'African Rose' fruit extracts

\begin{tabular}{|c|c|c|c|c|}
\hline \multirow{2}{*}{ Constituents } & \multicolumn{2}{|c|}{ 'Santa Rosa' extracts } & \multicolumn{2}{|c|}{ 'African Rose' extracts } \\
\hline & Ethanolic & Ethyl acetate & Ethanolic & Ethyl acetate \\
\hline $\begin{array}{c}\text { Total phenolic } \\
\text { (mg Gallic acid } / \mathrm{g} \text { DW) }\end{array}$ & $122.17 \pm 2.05^{\mathrm{a}}$ & $64.94 \pm 0.16^{b}$ & $486.08 \pm 4.07^{\mathrm{a}}$ & $116.849 \pm 1.15^{b}$ \\
\hline $\begin{array}{c}\text { Total flavonoid } \\
\text { (mg Quercetin /g DW) }\end{array}$ & $30.02 \pm 0.15^{\mathrm{a}}$ & $15.79 \pm 0.37^{\mathrm{b}}$ & $45.991 \pm 1.26^{\mathrm{a}}$ & $35.61 \pm 1.07^{\mathrm{b}}$ \\
\hline $\begin{array}{c}\text { Total tannin } \\
(\mathrm{mg} \text { Tannic acid } / \mathrm{g} \mathrm{DW})\end{array}$ & $8.71 \pm 0.14^{a}$ & $5.33 \pm 0.25^{\mathrm{b}}$ & $9.355 \pm 0.21^{a}$ & $5.823 \pm 0.34^{\mathrm{b}}$ \\
\hline $\begin{array}{l}\text { Total alkaloid } \\
(\mathrm{g} / 100 \mathrm{~g} \text { DW })\end{array}$ & $4.84 \pm 0.08^{\mathrm{a}}$ & $3.74 \pm 0.11^{\mathrm{b}}$ & $2.425 \pm 0.31^{a}$ & $1.316 \pm 0.11^{\mathrm{b}}$ \\
\hline $\begin{array}{c}\text { Total anthocyanin } \\
\text { (mg cy-3-glu / 100g FW) }\end{array}$ & $164.13 \pm 1.78^{a}$ & $97.51 \pm 0.46^{b}$ & $326.83 \pm 1.68^{a}$ & $206.48 \pm 2.08^{\mathrm{b}}$ \\
\hline
\end{tabular}


extract of 'Santa Rosa' 18.416 then the ethyl acetate extract of 'African rose' 28.532 and 'Santa Rosa' 31.522 was the lowest. IC 50 value indicates the concentration of the test sample required to inhibit $50 \%$ of free radicals. The $\mathrm{IC}_{50}$ value is widely a factor used to measure the free radical scavenging activity (Cuvelier et al., 1992); a lesser IC 50 value corresponds to a higher antioxidant activity. The four extracts of plum showed a significant dose-dependent inhibition of DPPH activity. Enzymatic and nonenzymatic antioxidants are molecules that have the capability to scavenge free radicals before they damage cells. Antioxidants can be endogenous or obtained exogenously, either from diet or from dietary supplements (Li et al., 2014). Scientific evidence recommends that antioxidant compounds in food play a significant role as a health protecting factor.

The ethanolic extract of 'African rose' and 'Santa Rosa' has got a higher reducing power $30.24 \pm 0.45$ and $25.34 \pm$ 0.53 respectively, then the ethyl acetate extract of them $21.08 \pm 0.18$ and $16.21 \pm 0.25 \mathrm{mg} / \mathrm{g} \mathrm{DW}$ respectively.

According to Phongpaichit et al. (2007), extracts which have $\mathrm{IC}_{50}$ values ranging from 50 to $100 \mathrm{mg} / \mathrm{ml}$ is considered to display intermediate antioxidant activity. For now, extracts with $\mathrm{IC}_{50}$ values ranging between 10 to $50 \mathrm{mg}$ $/ \mathrm{ml}$ is considered to have strong antioxidant activity. In this case, the four extracts of 'African Rose' and 'Santa Rosa' possessed strong antioxidant activity. While the ethanolic extracts are the best of them. The antioxidant capacity found in plum fruit pulp values was set between 44.18 and 49.23\% (Vlaic et al. 2017). They assumed that Differences depending on the variety antioxidant capacity registered during maturation. Also Sójka et al. (2015) found that antioxidant activity, $1.036 \mathrm{mM} \mathrm{TE} / \mathrm{g}$.

A Pearson product-moment correlation coefficient was computed to evaluate the relationship between total phenolics and $\mathrm{IC}_{50}(\mu \mathrm{g} / \mathrm{ml})$ of different extracts. The results suggest that all the correlation was statistically significant. Statistical analysis indicated A strong negative correlation were found between both Total phenolics and $\mathrm{IC}_{50}(\mathrm{r} 2=$ $0.635, \mathrm{p} \leq 0.05)$ (Fig. 1). Results identified by Díaz Mula $e t$ al. (2009), approving that the phenolic compounds, are in correlation with the antioxidant capacity.

\section{HPLC analysis of phenolic and flavonoid compounds}

Data in Table 4 showed that the concentration of several phenolic compounds and flavonoids was identified. Myricetin was dominating $(97.62 \mu \mathrm{g} / \mathrm{mg} \mathrm{DW})$ in 'Santa Rosa' fruit followed by ellagic acid and benzoic acid. While in 'African rose' fruit extract Ellagic acid was dominating $(122.30 \mu \mathrm{g} / \mathrm{mg} \mathrm{DW})$ followed by myricetin then vanillin. chlorogenic acid was dominant in three plum species $P$. cerasifera Ehrh., P. domestica L., and P. spinosa L. 11.95, 11.565 , and $12.985 \mathrm{mg} \mathrm{kg}^{-1}$ fw respectively (Celik et al., 2017). Additionally, Sójka et al. (2015) found that the dominant compound in fresh plum pomace was

Table 3. Antioxidant activity of 'Santa Rosa' and 'African Rose' fruit extracts against DPPH method

\begin{tabular}{|c|c|c|c|c|}
\hline \multirow{2}{*}{ Conc. $(\mu \mathrm{g} / \mathrm{ml})$} & \multicolumn{2}{|c|}{ 'Santa Rosa' } & \multicolumn{2}{|c|}{ African Rose' } \\
\hline & DPPH \% in ethanolic extract & DPPH \% in ethyl acetate extract & DPPH \% in ethanolic extract & DPPH \% in ethyl acetate extract \\
\hline 40 & 43.897 & 43.447 & 58.957 & 56.287 \\
\hline 80 & 48.933 & 46.862 & 66.667 & 61.252 \\
\hline 120 & 58.463 & 54.589 & 73.156 & 62.008 \\
\hline 150 & 70.032 & 63.677 & 81.143 & 62.763 \\
\hline $\mathrm{IC}_{50}(\mu \mathrm{g} / \mathrm{ml})$ & 18.416 & 31.522 & 13.923 & 28.532 \\
\hline $\begin{array}{l}\text { Reducing power activity } \\
(\mu \mathrm{g} \text { Gallic acid } / 100 \mathrm{gDW}\end{array}$ & $25.34 \pm 0.53$ & $16.21 \pm 0.25$ & $30.24 \pm 0.45$ & $21.08 \pm 0.18$ \\
\hline
\end{tabular}

Table 4. HPLC analysis of phenolic and flavonoid compounds 'Santa Rosa' and 'African Rose' fruit extracts

\begin{tabular}{|c|c|c|c|}
\hline \multirow{2}{*}{ No. } & \multirow{2}{*}{ Compounds } & \multicolumn{2}{|c|}{ Conc. $\mu \mathrm{g} / \mathrm{mg}$ DW } \\
\hline & & 'Santa Rosa' & 'African Rose' \\
\hline 1 & Pyrogallol & 4.5 & 6.38 \\
\hline 2 & Quinol & 1.27 & - \\
\hline 3 & Gallic acid & 2.40 & 2.45 \\
\hline 4 & Catechol & 1.55 & 5.04 \\
\hline 5 & $p$-Hydroxy benzoic acid & 1.45 & 5.92 \\
\hline 6 & Caffeine & 2.52 & 5.10 \\
\hline 7 & Chlorgenic acid & 1.57 & 1.24 \\
\hline 8 & Vanillic acid & 1.81 & 3.79 \\
\hline 9 & Caffeic acid & 1.08 & 3.53 \\
\hline 10 & Syringic acid & 1.81 & 4.52 \\
\hline 11 & Vanillin & 5.35 & 14.17 \\
\hline 12 & $p$-Coumaric acid & 1.83 & 2.60 \\
\hline 13 & Ferulic acid & 1.41 & 1.06 \\
\hline 14 & Benzoic acid & 17.37 & 4.18 \\
\hline 15 & Rutin & 4.9 & 12.88 \\
\hline 16 & Ellagic acid & 37.21 & 122.30 \\
\hline 17 & o- Coumaric acid & 4.52 & 9.79 \\
\hline 18 & Salicylic acid & 1.17 & 5.43 \\
\hline 19 & Myricetin & 97.62 & 19.24 \\
\hline 20 & Cinnamic acid & 9.32 & 1.07 \\
\hline 21 & Quercitin & 1.50 & 6.93 \\
\hline 22 & Rosmarinic acid & 8.14 & 1.02 \\
\hline 23 & Neringenin & 4.30 & 2.44 \\
\hline 24 & Kaempferol & 8.33 & 3.20 \\
\hline
\end{tabular}


400

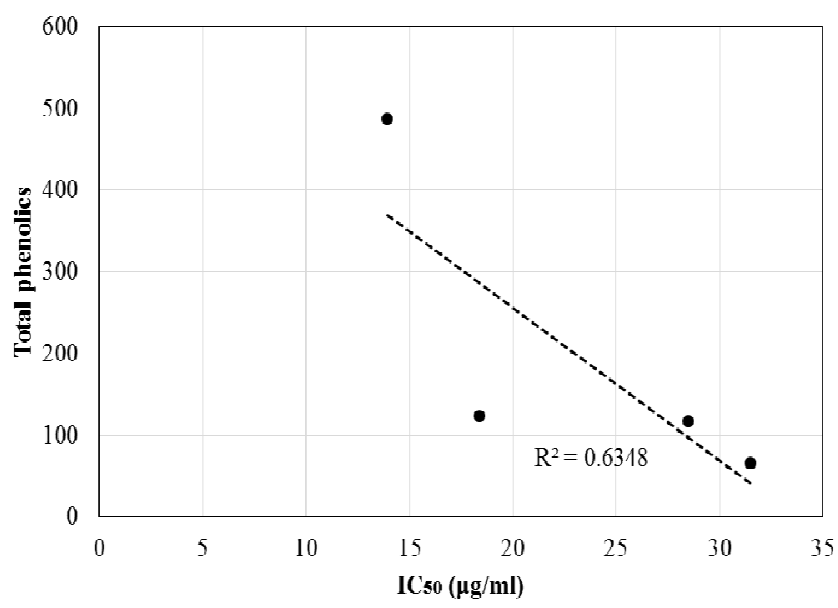

Fig. 1. Correlation between total phenolics and $\mathrm{IC}_{50}(\mu \mathrm{g} / \mathrm{ml})$

neochlorogenic acid $(6.42 \mathrm{mg} / 100 \mathrm{~g}$ fresh weight).

GC-MS analysis of biomolecules on the plum fruit extract

The GC-MS analysis of 'Santa Rosa' fruit revealed the presence of fourteen compounds while in 'African rose' there was twenty one compounds that could contribute the therapeutic quality of the plant (Figs. 2 and 3). The identification of the phytochemical compounds was based on the peak area, retention time and molecular formula. The active principles with their retention time (RT), molecular weight (MW), molecular formula and peak area in percentage of 'Santa Rosa' are presented in Fig. 1. The main compounds present in the fruits were Cyclohexanol, 5-methyl-2-(1-methylethyl)- 3-p-Menthanol (35.28\%), Thymol (14.15\%) etc. other minor compounds were also present (Table 5). Where GC-MS profiles of 'African rose' fruit is shown in Fig. 2. The main compounds present in the fruits were 7-Methyl-7-(1-methylethenyl)-2-phenylbicyclo [4.2.0] oct-1-ene (35.33\%), glycine, $\mathrm{N}$-methyl- $\mathrm{N}$-methoxycarbonyl-, nonyl ester $(21.07 \%$ ) etc. other major and minor compounds were also present (Table 6).

Thymol is one among the 14 compounds from the fruit of 'Santa Rosa'. Thymol is a natural mono-terpenoid phenol which has strong antiseptic properties. The terpenoids, mainly the mono-terpenols, donate fruity characteristics to the aroma of fruits, most of which are defined as very pleasant (Coelho et al., 2006). Likewise, Chai et al. (2012) described that the terpenoid content of $P$. domestica was relatively low as the main content was only $2.52 \mu \mathrm{g} \mathrm{kg}-1$ FW. In $P$. salicina hybrids, the terpenoid content was relatively high and represented $10.0 \%$ of the total volatiles.

\section{Antimicrobial activity of plums}

The agar diffusion method used to evaluate the antibacterial and antifungal activity of ethanolic and ethyl acetate extracts of 'Santa Rosa' and 'African rose' plums by using selected gram-positive, gram-negative bacteria and fungus. The diameter of the inhibition zone (ZI) is shown in Table 7. The data show that the extract exhibited the activity against the examined food pathogens. Gram positive bacteria Staphylococcus aureus and Bacillus cereus demonstrated almost the same susceptibility of the Gramnegative Escherichia coli and Salmonella typhimureum. The
'African rose' ethanolic extract exhibited antibacterial activity against Staphylococcus aureus (ZI $=18.51 \mathrm{~mm})$, one of the most common gram-positive bacterium causing food poisoning. On the other hand, a weak antimicrobial activity of 'Santa Rosa' ethyl acetate extract was detected against $B$. cereus $(\mathrm{ZI}=9.18 \mathrm{~mm})$. The effect was equivalent to that of kanamycin, and polymyxin used as positive control. The extracts exposed no effect on the fungus used (Aspergillus niger and Candida albicans). In terms of antimicrobial potential, gram-positive and gram-negative bacteria have been found susceptible to the $P$. domestica extract for example Gram-positive strain of $S$. aureus $(19.7 \pm 0.4 \mathrm{~mm})$ and Gram negative strains of E. coli $(14.4 \pm 0.7 \mathrm{~mm})$ (Islam et al., 2017). Moreover, Mehta et al. (2014) found that $S$. aureus $(\mathrm{ZI}=16 \mathrm{~mm})$ which is near to our results. Sójka et al. (2015) results haven't shown antimicrobial effects of plum pomaces against e gram-negative bacteria $E$. coli.

\section{Anticancer activity of plums}

Results showed that 'Santa Rosa' and 'African rose' extracts had cytotoxic effects on Liver cell line, colorectal adenocarcinoma, and breast cancer cell line and this effect were concentration dependent (Table 8). We used five different concentration of plant extract, it was found that as plant concentration was increased, the cell viability decreased and anticancer activity increased. The $\mathrm{IC}_{50}$ of 'African rose' and 'Santa Rosa' against Colorectal adenocarcinoma (Caco-2) was 4 and $8.5 \mu \mathrm{g} / \mathrm{ml}$ respectively. The value of $\mathrm{IC}_{50}$ was found to be $99.97 \mu \mathrm{g} / \mathrm{ml}$ against MCF-7 (breast cancer) cell line (Poongodi et al., 2015). While our results showed that the cytotoxicity assay, which was carried out in MCF-7 (breast cancer) cell line had an $\mathrm{IC}_{50}$ of 'African rose' and 'Santa Rosa' 38.8 and $43.5 \mu \mathrm{g} / \mathrm{ml}$ respectively. Also Demir et al. (2017) found that IC 50 of their extract of Prunus laurocerasus against MCF-7 was > $500 \mu \mathrm{g} / \mathrm{ml}$. Their results also showed IC 50 against HepG2 was $357.1 \mu \mathrm{g} / \mathrm{ml}$. The IC $\mathrm{IC}_{50}$ of Prunus domestica fruit peel against HepG2 was $23.2 \mu \mathrm{g} / \mathrm{ml}$ (Ateya et al., 2014). While our results showed that $\mathrm{IC}_{50}$ of Prunus domestica fruit against HepG2 was 25.5 and $23.1 \mu \mathrm{g} / \mathrm{ml}$ of 'Santa Rosa' and 'African rose' respectively. 


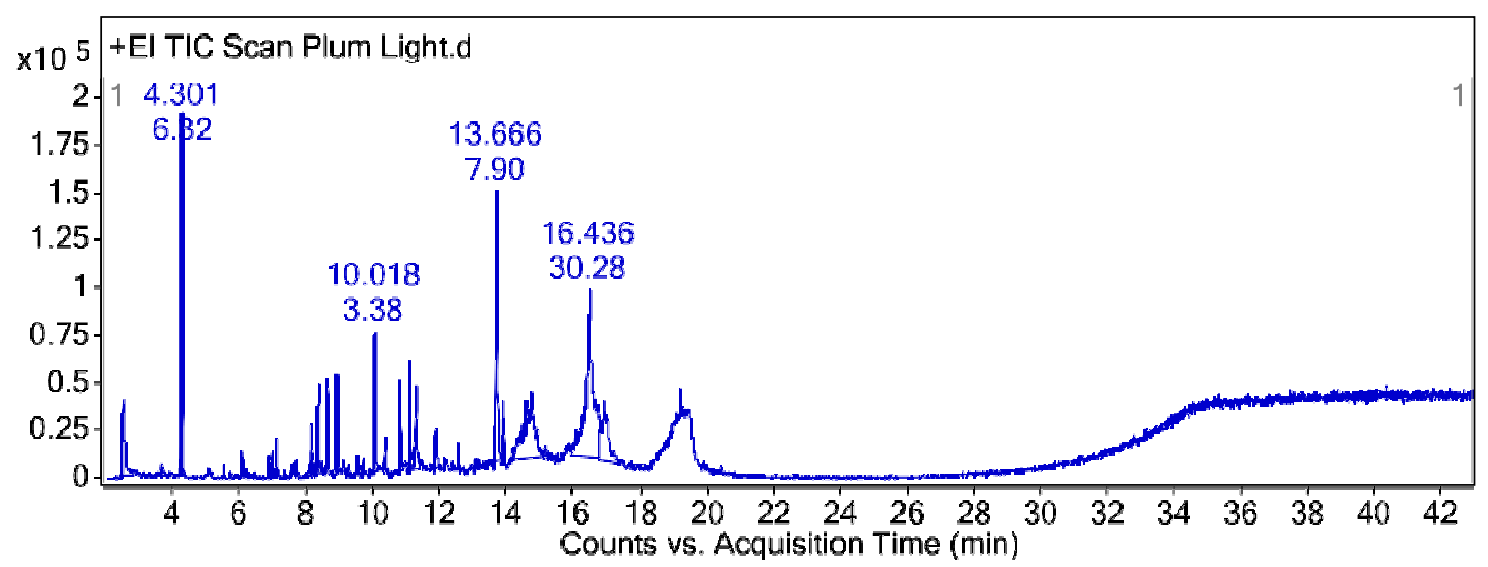

Fig 2. GC-MS profiles of 'Santa Rosa' fruit

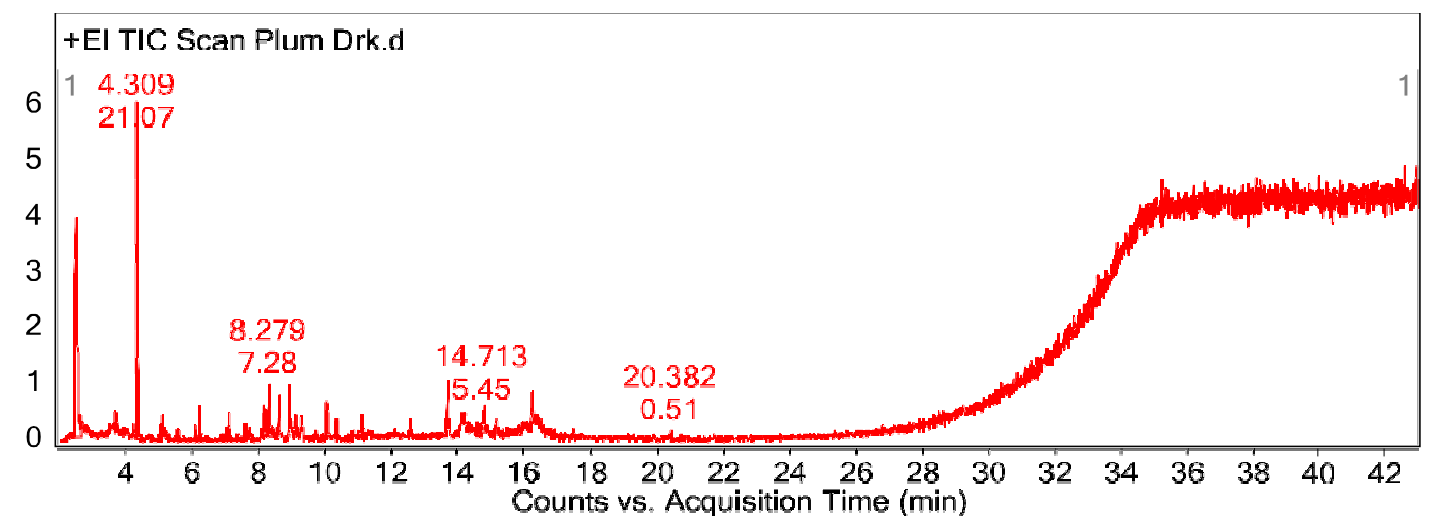

Fig. 3. GC-MS profiles of 'African Rose' fruit

Table 5. Compounds present in the 'Santa Rosa' fruit using GC-MS analysis

\begin{tabular}{|c|c|c|c|c|}
\hline No. & $\begin{array}{l}\text { Peak } \\
\text { name }\end{array}$ & $\begin{array}{l}\text { Retention } \\
\text { time }\end{array}$ & $\begin{array}{c}\text { Peak } \\
\text { area }\end{array}$ & $\begin{array}{c}\% \\
\text { Peak area }\end{array}$ \\
\hline 1 & $\begin{array}{l}\text { Ambrosiol (8,9-dihydroxy-6,9a-dimethyl-3-methylidene-decahydro- } \\
\text { azuleno[4,5-b]furan-2(3h)-one) Formula: } \mathrm{C}_{15} \mathrm{H}_{22} \mathrm{O}_{4} \mathrm{MW}: 266.337\end{array}$ & 2.521 & 251220.64 & 5.25 \\
\hline 2 & 2-Imidazolidinethione Formula: $\mathrm{C}_{8} \mathrm{H}_{16} \mathrm{~N}_{4} \mathrm{O}_{4} \mathrm{MW}: 102.16$ & 3.649 & 65602.97 & 2.37 \\
\hline 3 & $\begin{array}{l}\text { 4-amino-3,5-bis(dimethoxymethyl)-4H-1,2,4-triazole } \\
\text { Formula: } \mathrm{C}_{15} \mathrm{H}_{22} \mathrm{O}_{4} \text { MW:232.237 }\end{array}$ & 4.301 & 302154.31 & 6.32 \\
\hline 4 & 4-methylhex-4-en-1-ol Formula: $\mathrm{C}_{7} \mathrm{H}_{14} \mathrm{O}$ MW:114.188 & 8.335 & 171532.11 & 3.59 \\
\hline 5 & 2-Octanone Formula: $\mathrm{C}_{8} \mathrm{H}_{16} \mathrm{O}$ MW: 128.215 & 8.625 & 134606.55 & 3.82 \\
\hline 6 & 2,2-Dimethylcyclohexanone Formula: $\mathrm{C}_{8} \mathrm{H}_{14} \mathrm{O}$ MW: 126.2 & 8.931 & 144701.63 & 4.03 \\
\hline 7 & Ethyl 4-oxo-8-methyldecanoate Formula: $\mathrm{C}_{13} \mathrm{H}_{24} \mathrm{O}_{3} \mathrm{MW}: 228.332$ & 10.018 & 161382.5 & 4.38 \\
\hline 8 & 2-heptanoylfuran Formula: $\mathrm{C}_{11} \mathrm{H}_{16} \mathrm{O}_{2} \mathrm{MW}: 180.247$ & 10.783 & 122799.66 & 2.63 \\
\hline 9 & B.-methylstyrene Formula: $\mathrm{C}_{9} \mathrm{H}_{10} \mathrm{MW}: 118.179$ & 11.089 & 123993.72 & 3.99 \\
\hline 10 & $\begin{array}{l}\text { Phosphonic acid, methyl-, bis(trimethylsilyl) ester } \\
\text { Formula: } \mathrm{C}_{7} \mathrm{H}_{21} \mathrm{O}_{3} \mathrm{PS}_{\mathrm{i} 2} \mathrm{MW}: 240.38\end{array}$ & 11.838 & 57248.4 & 2.2 \\
\hline 11 & 2,4-Dicyanoaniline Formula: $\mathrm{C}_{8} \mathrm{H}_{5} \mathrm{~N}_{3} \mathrm{MW}: 143.149$ & 13.666 & 377501.08 & 9.9 \\
\hline 12 & 2,2-Bis(4-hydroxyphenyl) propane Formula: $\mathrm{C}_{15} \mathrm{H}_{16} \mathrm{O}_{2} \mathrm{MW}: 228.29$ & 13.876 & 52031.07 & 2.09 \\
\hline 13 & $\begin{array}{l}\text { Cyclohexanol, 5-methyl-2-(1-methylethyl)-3-p-Menthanol } \\
\text { Formula: } \mathrm{C}_{10} \mathrm{H}_{20} \mathrm{O} \text { MW: } 156.2652\end{array}$ & 16.436 & 1447840.82 & 35.28 \\
\hline 14 & Thymol Formula: $\mathrm{C}_{10} \mathrm{H}_{14} \mathrm{O}$ MW: 150.221 & 16.887 & 437589.04 & 14.15 \\
\hline
\end{tabular}


402

Table 6. Compounds present in the 'African Rose' fruit using GC-MS analysis

\begin{tabular}{|c|c|c|c|c|}
\hline No. & $\begin{array}{l}\text { Peak } \\
\text { name }\end{array}$ & $\begin{array}{l}\text { Retention } \\
\text { time }\end{array}$ & $\begin{array}{r}\text { Peak } \\
\text { area }\end{array}$ & $\begin{array}{c}\% \\
\text { Peak area }\end{array}$ \\
\hline 1 & $\begin{array}{l}\text { 7-Methyl-7-(1-methylethenyl)-2-phenylbicyclo[4.2.0]oct-1-ene } \\
\text { Formula: } \mathrm{C}_{18} \mathrm{H}_{22} \mathrm{MW}: 238.374\end{array}$ & 2.473 & 177523.2 & 35.33 \\
\hline 2 & $\begin{array}{l}\text { Glycine, } \mathrm{N} \text {-methyl-N-methoxycarbonyl-, nonyl ester } \\
\text { Formula: } \mathrm{C}_{14} \mathrm{H}_{27} \mathrm{NO}_{4} \mathrm{MW}: 273.3685\end{array}$ & 4.309 & 105757.53 & 21.07 \\
\hline 3 & $\begin{array}{l}\text { 4-Methyl-2,4-bis(4'-trimethylsilyloxyphenyl)pentene-1 } \\
\text { Formula: C24H36O2Si2 MW: } 412.72\end{array}$ & 4.72 & 3480.78 & 0.69 \\
\hline 4 & Tri chloro mono fluoro methane Formula: CFCl3 MW: 137.359 & 5.082 & 10950.26 & 3.72 \\
\hline 5 & Glycine, n-methyl-n-ethoxycarbonyl-, ethyl ester Formula: $\mathrm{C}_{8} \mathrm{H}_{15} \mathrm{NO}_{4} \mathrm{MW}: 189.21$ & 5.541 & 3440.43 & 0.69 \\
\hline 6 & 3-Phenyl-1,3-pentanediol Formula: $\mathrm{C}_{11} \mathrm{H}_{16} \mathrm{O}_{2} \mathrm{MW}: 180.247$ & 6.065 & 3821.97 & 0.76 \\
\hline 7 & Bromoacetylene & 7.039 & 4288.74 & 0.85 \\
\hline 8 & Benzene, 1-fluoro-4-methyl-Formula:C_HzFMW: 110.1289 & 7.095 & 8966.41 & 1.79 \\
\hline 9 & Ethyl 2-(ethoxycarbonyloxy) ethylcarbamate Formula: $\mathrm{C}_{8} \mathrm{H}_{15} \mathrm{NO}_{5} \mathrm{MW}: 205.2084$ & 7.506 & 3834.27 & 0.76 \\
\hline 10 & 2-methyl-5-(methylthio)- Furan Formula:C6 $\mathrm{H}_{8} \mathrm{OS}$ MW: 128.189 & 7.578 & 4172.29 & 0.83 \\
\hline 11 & 1-Phenethyl-4-piperidone Formula: $\mathrm{C}_{13} \mathrm{H}_{17} \mathrm{NO}$ MW: 203.28 & 8.134 & 19394.37 & 3.86 \\
\hline 12 & $\begin{array}{l}\text { Pentanamide, 2-(dimethylamino)- } \mathrm{N} \text {-[7-(hydroxyphenylmethyl)-3-(1-methylethyl)- } \\
\text { 5,8-dioxo-2-oxa-6,9-diazabicyclo hexadeca-12,14,15-trien-4-yl]-3-methyl Formula: } \\
\qquad \mathrm{C}_{31} \mathrm{H}_{44} \mathrm{~N}_{4} \mathrm{O}_{5} \mathrm{MW}: 552.716\end{array}$ & 8.279 & 36551.51 & 7.28 \\
\hline 13 & D-proline, n-methoxycarbonyl-, octyl ester Formula: $\mathrm{C}_{15} \mathrm{H}_{27} \mathrm{NO}_{4} \mathrm{MW}: 285.38$ & 8.577 & 18150.9 & 3.62 \\
\hline 14 & Ropivacaine Formula: $\mathrm{C}_{17} \mathrm{H}_{26} \mathrm{~N}_{2} \mathrm{O}$ MW: 274.4054 & 8.883 & 28321.83 & 5.64 \\
\hline 15 & Acetoxyacetic acid, 2-naphthyl ester Formula: $\mathrm{C}_{14} \mathrm{H}_{12} \mathrm{O}_{4} \mathrm{MW}: 244.24$ & 10.01 & 17026.87 & 3.39 \\
\hline 16 & Phenol, 4-ethyl- Formula: $\mathrm{C}_{8} \mathrm{H}_{10} \mathrm{O} \mathrm{MW}: 122.1644$ & 10.324 & 5025.6 & 1 \\
\hline 17 & 1,4-dihydro-1-methyl-3-Pyridinecarbonitrile Formula: $\mathrm{C}_{7} \mathrm{H}_{6} \mathrm{~N}_{2} \mathrm{MW}: 118.1$ & 11.089 & 6114.98 & 1.22 \\
\hline 18 & 3-Cyano-4,6-dimethyl-2-hydroxypyridine Formula: $\mathrm{C}_{8} \mathrm{H}_{8} \mathrm{~N}_{2} \mathrm{O}$ MW: 148.16 & 12.531 & 4907.41 & 0.98 \\
\hline 19 & N-(1-Naphthyl) cyclohexanecarboxamide Formula: $\mathrm{C}_{1}-\mathrm{H}_{1}$ NO MW: 253.339 & 14.713 & 27357.26 & 5.45 \\
\hline 20 & Isophthalic acid, 2-formylphenyl propyl ester Formula: $\mathrm{C}_{18} \mathrm{H}_{15} \mathrm{O}_{5} \mathrm{MW}: 312.3166$ & 15.099 & 2812.5 & 0.56 \\
\hline 21 & $\begin{array}{l}\text { Ethaneperoxoic acid, 1-cyano-1-[2-(2-phenyl-1,3-dioxolan-2yl)eth] pentyl ester } \\
\text { Formula: } \mathrm{C}_{19} \mathrm{H}_{25} \mathrm{NO} \text { s } \mathrm{MW}: 347.411\end{array}$ & 20.382 & 2552.25 & 0.51 \\
\hline
\end{tabular}

Table 7. Antibacterial activities of 'Santa Rosa' and 'African Rose' fruit extracts against selected bacterial strains and fungus

\begin{tabular}{|c|c|c|c|c|c|c|}
\hline \multirow{3}{*}{ Samples } & \multicolumn{6}{|c|}{ Inhibition zone $(\mathrm{mm})^{*}$} \\
\hline & \multicolumn{2}{|c|}{$\begin{array}{c}\text { Gram positive } \\
\text { bacteria }\end{array}$} & \multicolumn{2}{|c|}{$\begin{array}{c}\text { Gram negative } \\
\text { bacteria }\end{array}$} & \multicolumn{2}{|c|}{ Fungus } \\
\hline & S. aureus & B. cereus & E. coli & S. typhimureum & A. niger & C. albicans \\
\hline 'Santa Rosa' ethanolic extract & $15.24 \pm 0.15$ & $11.34 \pm 0.22$ & $13.17 \pm 0.36$ & $16.22 \pm 0.44$ & - & - \\
\hline ‘Santa Rosa’ ethyl acetat extract & $12.14 \pm 0.31$ & $9.18 \pm 0.43$ & $10.55 \pm 0.28$ & $12.19 \pm 0.35$ & - & - \\
\hline 'African Rose' ethanolic extract & $18.51 \pm 0.17$ & $14.10 \pm 0.31$ & $15.41 \pm 0.30$ & $18.36 \pm 0.21$ & - & - \\
\hline 'African Rose' ethyl acetat extract & $13.62 \pm 0.27$ & $12.58 \pm 0.27$ & $12.19 \pm 0.08$ & $14.63 \pm 0.48$ & - & - \\
\hline
\end{tabular}

Values are mean \pm SD of three replicate analyses

Table 8. Anticancer activities of 'Santa Rosa' and 'African Rose' ethanolic extracts

\begin{tabular}{ccccccc}
\hline \multirow{2}{*}{$\begin{array}{c}\text { Concentrations } \\
(\mu \mathrm{g} / \mathrm{ml})\end{array}$} & $\begin{array}{c}\text { Liver cell line (HepG2) } \\
\text { Viability } \%\end{array}$ & $\begin{array}{c}\text { Colorectal adenocarcinoma } \\
\text { (Caco-2) cell line } \\
\text { Viability } \%\end{array}$ & \multicolumn{2}{c}{$\begin{array}{c}\text { Breast cell line (MCF-7) } \\
\text { Viability \% }\end{array}$} \\
\cline { 2 - 7 } & 'Santa Rosa' & 'African Rose' & 'Santa Rosa' & 'African Rose' & 'Santa Rosa' & 'African Rose' \\
\hline 500 & 100 & 100 & 100 & 95 & 100 & 100 \\
1000 & 89.5 & 87 & 99 & 93.6 & 88.8 & 86.7 \\
1500 & 80.3 & 77 & 87.6 & 82.6 & 83 & 82.6 \\
2000 & 72 & 70 & 79 & 71 & 78 & 79 \\
3000 & 65 & 61 & 57 & 51 & 67 & 64 \\
IC 50 \\
\hline
\end{tabular}




\section{Conclusions}

The multitarget therapeutic potential of the $P$. domestica was explored in different in vitro testing examples. Both the 'African rose' and 'Santa Rosa' possessed selective effects in inhibition of cancer cells, pathogenic bacteria, oxidation, thereby representing its use as a value-added component for functional food.

\section{Acknowledgements}

Authors would like to show appreciation to Faculty of Agriculture, Cairo University for continuing cooperation to support research that provided facilities necessary to accomplish the most wanted objectives of the research.

\section{References}

Abdel-Rahim EA, El-Beltagi HS (2010). Constituents of apple, parsley and lentil edible plants and their therapy treatments for blood picture as well as liver and kidneys functions against lipidemic disease. Electronic Journal of Environmental, Agricultural and Food Chemistry 9(6):1117-1127.

Ateya AM, Abou-Hashem M, El-Sayed Z, Abbas F (2014). Biological activity of the Egyptian medicinal plants: part 4 Cytotoxicity of 50 Egyptian plants and spices against hepatocellular carcinoma. Journal of Ethnomedicine 1:56-63.

Bagavathi PE, Ramasamy N (2012). GC-MS analysis of phytocomponents in the ethanol extract of Polygonum chinense L. Pharmacognosy Research 4(1):11-14.

Bauer AW, Kirby WM, Sherris JC, Turck M (1966). Antibiotic susceptibility test-ing by a standardized single disk method. American Journal of Clinical Pathology 45(4):493-496.

Cai Y, Luo Q, Sun M, Corke H (2004). Antioxidant activity and phenolic compounds of 112 traditional Chinese medicinal plants associated with anticancer.Life Sciences 74(17):2157-2184.

Celep E, Aydın A, Yeşilada E (2012). A comparative study on the in vitro antioxidant potentials of three edible fruits: Cornelian cherry, Japanese persimmon and cherry laurel, Food and Chemical Toxicology 50(9):3329-3335.

Celik F, Gundogdu M, Alp S, Muradoglu F, Ercişli S,Gecer MK, Canan I (2017). Determination of phenolic compounds, antioxidant capacity and organic acids contents of Prunus domestica L, Prunus cerasifera Ehrh. and Prunus spinosa L. fruits by HPLC. Acta Chromatographica 29(4):507-510.

Chai Q, Wu B, Liu W, Wang L, Yang C, Wang Y, Fang J, Liu Y, Li S (2012). Volatiles of plums evaluated by HSSPME with GC-MS at the germplasm level. Food Chemistry 130(2):432-440.

Chou HJ, Kuo JT, Lin ES (2009). Comparative antioxidant properties of water extracts from different parts of beefsteak plant (Perilla frutescens). Journal of Food and Drug Analysis 17(6):489-496.

Coelho E, Rocha SM, Delgadillo I, Coimbra MA (2006). HeadspaceSPME applied to varietal volatile compounds evolution during Vitis vinifera L. cv. 'Baga' ripening. Analytica Chimica Acta 563(1-2):204 214.
Costa JGM, Leite GO, Dubois AF, Seeger RL, Boligon AA, Athayde ML, Campos AR, Rocha JBT (2012). Antioxidant effect of Stryphnodendron rotundifolium Martius extracts from Cariri-Ceará state (Brazil): Potential involvement in its therapeutic use. Molecules 17(1):934950.

Cuvelier ME, Richard H, Berset C (1992). Comparison of the antioxidative activity of some acid-phenols: Structure activity relationships. Bioscience, Biotechnology, and Biochemistry 56(2):324325.

Dai J, Mumper RJ (2010). Plant phenolics: extraction, analysis and their antioxidant and anticancer properties. Molecules 15(10):7313-7352.

Demir S, Turan I, Demir F, Ayazogiu Demir E, Aliyazicioglu Y (2017). Cytotoxic effect of Laurocerasus officinalis extract on human cancer cell lines. Marmara Pharmaceutical Journal 21:121-126.

Dhingra N, Sharma R, Kar A (2014). Evaluation of the antioxidant activities of Prunus domestica whole fruit: an in vitro study. International Journal of Pharmacy and Pharmaceutical Sciences 6:271-276.

Díaz-Mula HM, Zapata PJ, Guillén F, Martínez-Romero D, Castillo S, Serrano M, Valero D (2009). Changes in hydrophilic and lipophilic antioxidant activity and related bioactive compounds during postharvest storage of yellow and purple plum cultivars. Postharvest Biology and Technology 51(3):354-363.

Djeridane A, Yousfi M, Nadjemi B, Boutassouna D, Stocker P, Vidal N (2006). Antioxidant activity of some algerian medicinal plants extracts containing phenolic compounds. Food Chemistry 97(4):654660.

Dugalic K, Sudar R, Viljevac M, Josipovic M, Cupic T (2014). Sorbitol and sugar composition in plum fruits influenced by climatic conditions. Journal of Agricultural Science and Technology 16(5):1145-1155.

Eivind V, Rune SS (2006). Methods to determine antioxidative capacity in fruit. Journal of Fruit and Ornamental Plant Research 14:123-131.

El-Beltagi HES (2011). Effect of roasting treatments on protein fraction profiles, some enzyme activities of Egyptian peanuts. International Journal of Food Science and Nutrition 62(5):453-456.

El-Beltagi HS, Mohamed HI, Megahed BMH, Gamal M, Safwat G(2018). Evaluation of some chemical constituents, antioxidant, antibacterial and anticancer activities of Beta vulgaris L. root. Fresenius Environmental Bulletin 27(9):6369-6378.

Erkan N (2012). Antioxidant activity and phenolic compounds of fractions from Portulaca oleracea L. Food Chemistry 133(3):775-781.

Gil MI, Tomás-Barberán FA,Hess-Pierce B, Kader AA (2002). Antioxidant capacities, phenolic compounds, carotenoids, and vitamin $\mathrm{C}$ contents of nectarine, peach, and plum cultivars from California. Journal of Agricultural and Food Chemistry 50(17):4976-4982.

Goupy P, Hugues M, Biovin P, Amiot MJ (1999). Antioxidant composition and activity of barley (Hordeum vulgare) and malt extracts and of isolated phenolic compounds. Journal of the Science of Food and Agriculture 79(12):1625-1634.

Harbone JB (1998). A guide to modern techniques of plant analysis. Second Ed, Chapman and Hall,London, pp 5484.

Islam NU, Amin R, Shahid M, Amin M, Zaib S, Iqbal J (2017). A multitarget therapeutic potential of Prunus domestica gum stabilized nanoparticles exhibited prospective anticancer, antibacterial, ureaseinhibition, anti-inflammatory and analgesic properties.BMC Complementary and Alternative Medicine 17(1):276. 
404

Jeyanthi RL, Sharmila S, Das MP, Seshiah C (2014). Extraction and purification of carotenoids from vegetables. Journal of Chemical and Pharmaceutical Research 6(4):594-598.

Karabegovic IT, Stojicevic SS, Velickovic DT, Nikolic NC, Lazic ML (2014). Optimization of microwave-assisted extraction of cherry laurel fruit. Separation Science and Technology 49(3):416-423.

Kayano S, Kikuzaki H, Fukutsuka N, Mitani T, Nakatani N (2002). Antioxidant activity of prune (Prunus domestica L.) constituents and a new synergist. Journal of Agricultural and Food Chemistry 50(13):3708-3712.

Kesba HH, El-Beltagi HS (2012). Biochemical changes in grape rootstocks resulted from humic acid treatments in relation to nematode infection. Asian Pacific Journal of Tropical Biomedicine 2(4):287-293.

Kikuzaki H, Kayano SI, Fukutsuka N, Aoki A, Kasamatsu K, Yamasaki Y, Mitani T, Nakatani N (2004). Abscisic acid related compounds and lignans in prunes (Prunus domestica L.) and their oxygen radical absorbance capacity (ORAC). Journal of Agricultural and Food Chemistry $52(2): 344349$.

Kim DO, Jeong SW, Lee CY (2003). Antioxidant capacity of phenolic phytochemicals from various cultivars of plums. Food Chemistry 81(3):321-326.

Kobeasy MI, El-Beltagi HS, El-Shazly MA, Khattab EA (2011). Induction of resistance in Arachis hypogaea L. against Peanut mottle virus by nitric oxide and salicylic acid. Physiological and Molecular Plant Pathology 76(2):112-118.

Lee J, Durst RW, Wrolstad RE (2005). Determination of total monomeric anthocyanin pigment content of fruit juices, beverages, natural colorants, and wines by the $\mathrm{pH}$ differential method: collaborative study.Journal of AOAC International 88(5):1269-1278.

Li Y, Brown RW, Bonner MR, Deng F, Tian L, Mu L (2014). Positive relationship between total antioxidant status and chemo-kines observed in adults. Oxidative Medicine and Cellular Longevity 693680.

Lombardi-Boccia G, Lucarini M, Lanzi S, Aguzzi A, Cappelloni M (2004). Nutrients and antioxidant molecules in yellow plums (Prunus domestica L.) from conventional and organic productions: A comparative study. Journal of Agricultural and Food Chemistry 52(1):90-94.

Mattila P, Astola J, Kumpulainen J (2000). Determination of flavonoids in plant material by HPLC with diode-array and electro-array detections. Journal of Agricultural and Food Chemistry48(12):5834-5841.

Mehta S, Soni N, Satpathy G, Gupta RK (2014). Evaluation of nutritional, phytochemical, antioxidant and antibacterial activity of dried plum (Prunus domestica). Journal of Pharmacognosy and Phytochemistry 3(2):166-171.

Orhan EI, Akkol KE (2011). Estimation of neuroprotective effects of Laurocerasus officinalis Roem. (cherry laurel) by in vitro methods. Food Research International 44(3):818-822.

Park HR, Park E, Rim AR, Jeon KI, Huang JH, Lee SC (2006). Antioxidant activity of extracts from Acanthopanax senticosus. African Journal of Biotechnology 5(23):2388-2396.

Phongpaichit S, Nikom J Rungjindamai N, Sakayaroj J, HutadilokTowatana N, Rukachaisirikul V, Kirtikara K(2007). Biological activities of extracts from endophytic fungi isolated from Garcinia plants. FEMS Immunology and Medical Microbiology 51(3):517-525.
Poongodi T, Srikanth R, Lalitha G (2015). Phytochemistry, GC-MS analysis and in vitro cytotoxic activity of Prunus angustifolia leaves against MCF-7 breast cancer cell line. World Journal of Pharmacy and Pharmaceutical Sciences 4:1489-1499.

Prior RL (2003). Fruits and vegetables in the prevention of cellular oxidative damage. The American Journal of Clinical Nutrition 78(3):570-578.

Repetto G, del Peso A, Zurita JL (2008). Neutral red uptake assay for the estimation of cell viability/cytotoxicity. Nature Protocols 3(7):11251131.

Sandra V, Ante G, Zoran S, Nadica D, Stjepan P, Jasmina D (2009). Chemical composition and antioxidant capacity of three plum cultivars. Agriculturae Conspectus Scientificus 74(3):273-276.

Saxena V, Mishra G, Saxena A, Vish-wakarma KR (2013). A comparative study on quantitative estimation of tannins in Terminalia chebula, Terminalia belerica, Terminalia arjuna and Saraca indica using spectrophotometer. Asian Journal of Pharmaceutical and Clinical Research 6(3):148-149.

Shallan MA, El-Beltagi HS, Mona AM, Amera TM, Sohir NA (2010). Effect of amylose content and pre-germinated brown rice on serum blood glucose and lipids in experimental animal. Australian Journal of Basic and Applied Sciences 4(2):114121.

Singleton V, Rossi J (1965). Colorimetry of total phenolics with phosphomolibdic-phosphotungstic acid reagents. The American Journal of Enology and Viticulture 16(3):144-158.

Sójka M, Kołodziejczyk K, Milala J, Abadias M, Viñas I, Guyot S, Baron A (2015). Composition and properties of the polyphenolic extracts obtained from industrial plum pomaces.Journal of Functional Foods 12:168-178.

Sumathy N, Sumathy J (2011). Antibacterial and antifungal activity of musa fruit peels against skin and gastrointestinal tract diseases. Herbal Tech Industry2:9-11.

Valko M, Leibfritz D, Moncol J, Cronin MTD, Mazur M, Telser J (2007). Free radicals and antioxidants in normal physiological functions and human disease. The International Journal of Biochemistry and Cell Biology 39(1):4484.

Vinson JA, Su X, Zubik L, Bose P (2001). Phenol antioxidant quantity and quality in foods: fruits. Journal of Agricultural and Food Chemistry 49(11):5315-5321.

Vlaic R, Socaci S, Muresan AE, Muresan C, Moldovan OP, Muste S, Muresan V (2017). Bioactive compounds and volatile profile dynamics during fruit growth of several plums cultivars. Journal of Agricultural Science and Technology 19:1565-1576.

Yang J, Martinson TE, Liu RH (2009). Phytochemical profiles and antioxidant activities of wine grapes. Food Chemistry 116(1):332-339.

Yaqeen Z, Naqvi N-u-H, Sohail T, Fatima N, Imran H (2013). Screening of solvent dependent antibacterial activity of Prunus domestica. Pakistan Journal of Pharmaceutical Sciences 26(2):409-414.

Zhishen J, Mengcheng T, Jianming W (1999). The determination of flavonoid contents in mulberry and their scavenging effects on superoxide radicals. Food Chemistry 64(4):555-559. 